\title{
AJARCDE

\section{Study of Herbal Toothpaste Made from Virgin Coconut Oil and Gambier (Uncaria gambir Roxb)}

\author{
Zaadah, Novizar Nazir and Novelina \\ Agricultural Product Technology Department, Faculty of Agricultural Technology, Andalas University. Indonesia
}

\section{ARTICLE INFO}

Article History:

Received: 12 September 2020

Final Revision: 2 November 2020

Accepted: 06 December 2020

Online Publication: 09 December 2020

\section{KEYWORDS}

gambier (Uncaria gambir roxb), virgin coconut oil, herbal toothpaste

\section{CORRESPONDING AUTHOR}

E-mail: nazir_novizar@yahoo.com

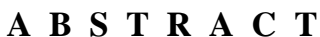

The study aimed to find out the effect of utilizing virgin coconut oil (VCO) and gambier (Uncaria gambir roxb) in several combinations on the manufacture of herbal toothpaste on its characteristics and antibacterial activity. The research design used is a Completely Randomized Design (CRD) with five treatments and three repeats so that in this study 5 x 3 there were 15 combinations of treatments. The resulting research data is then analyzed using the $\mathrm{F}$ test and if the data differs is real then proceed with the Duncan News Multiple Range Test (DNMRT) tests to find out the level of 5\% significant level between treatments. The determination of formulations in the manufacture of toothpaste using a concentration of $10 \% \mathrm{VCO}$ as a toothpaste base refers to the previous research formula and the addition of $0.9 \%, 1.8 \%, 2.6 \%, 3.5 \%$, and $4.3 \%$ of gambier. Based on research that has been done, it can be concluded that the addition of gambir concentrations has a real influence on the $\mathrm{pH}$ value and foam formation but does not affect homogeneity, hedonic values (color, aroma, taste, texture, and overall value) and the diameter of the bland zone against Streptococcus mutans bacteria. The best toothpaste preparation is treatment 3 , which is the addition of $2.6 \%$ of the toothpaste base preparation with a $\mathrm{pH}$ value of 8.42 , homogeneous, foam height of $10.70 \mathrm{~mm}$, color preference (3.85), the aroma (4.25), flavor (3.30), texture (3.45), overall (3.80), strong indicator bland zone diameter $(34.55 \mathrm{~mm})$.

\section{INTRODUCTION}

\subsection{Research Background}

Many commercial kinds of toothpaste tend to contain components of potentially damaging toothpaste ingredients to human health, most commonly sodium fluoride and triclosan [1]. Fluoride is not only effective in disrupting bacterial metabolic processes but shows the same effect that causes cell death in odontoblasts (dental cells). Triclosan, even in small concentrations such as in toothpaste, has been found to lower anticancer gene regulation [2]. So it takes an alternative herbal toothpaste that is relatively safer to consume and has antimicrobial capabilities that are just as effective as non-herbal ingredients. One way is to combine several herbal ingredients to improve the inhibition of pathogenic microbes.

The use of herbal toothpaste is more effective in lowering plaque index than non-herbal toothpaste. The same study conducted by Ref. [3] comparing toothpaste using herbal active ingredients (betel leaves, green tea leaves, and lime) with nonherbal active ingredients (standard toothpaste containing fluoride) states that both have antimicrobial effects but the use https://doi.org/10.29165/ajarcde.v4i3.89 of herbal toothpaste is more effective after 2 weeks of use. Previous research compared commercial and non-commercial herbal toothpaste stating that the index of plaque reduction of herbal toothpaste by $76.9 \%$ and in non-herbal toothpaste fluoride decreased the plaque index by $49.3 \%$ [4].

Research on antibacterial toothpaste has been done before, stating that lauric fatty acids show high antimicrobial activity against streptococcus mutans biofilms. Catechin tablets are enough to cause death in Streptococcus mutans, while the administration of $6 \%$ of catechins can kill $100 \%$ Streptococcus mutans within 1 hour [5]. Based on the description above, the author is interested in researching the use of VCO as a source of lauric acid and gambir as an antibacterial source in the manufacture of herbal toothpaste. As one of the world's leading coconut and gambir producer countries, the availability of virgin coconut oil and gambir raw materials is very abundant and easily available in Indonesia. Further development to increase the added value of this commodity product through its use in toothpaste because it has a high antimicrobial content 
potential as the main ingredient considered in all oral health products.

\subsection{Literature Review}

\subsubsection{Chemical Composition of Virgin Coconut Oil}

The main chemical composition of pure coconut oil or virgin coconut oil is dominated by saturated fatty acids $\pm 90 \%$ and unsaturated fatty acids $\pm 10 \%$. Saturated fatty acids are dominated by $\pm 53 \%$ lauric acid and $\pm 7 \%$ capric acid which is a medium-chain fatty acid, including $66 \%$ oil (Table 2 ), protein 6 $7 \%$ of its dry weight, water $48 \%$, coarse fiber $5 \%$, ash content $\pm 2 \%$ [6]. In addition to fatty acids, some other chemical components that have been known to be contained in virgin coconut oil are sterols, vitamin E, and polyphenol fractions (phenolic acids). These chemical components have antioxidant activity to prevent premature aging and maintain the vitality of the body Ref. [7]. The high low content is influenced by the quality of raw materials and the process of making virgin coconut oil , namely the use of heat can reduce antioxidant levels $\pm 25 \%$ can even be lost on excessive heating [8].

The ability of virgin coconut oil in killing bacteria is caused by the content of lauric acid, capric acid, miristic acid. Lauric acid in the human body is converted into a form of monoglyceride compounds namely monolaurin and capric acid converted into monocaprin which is antiviral, antibacterial, antifungal that can damage lipid membranes (virus wrapping layers) including HIV, influenza, and several other viruses.

The mechanism of antibacterial virgin coconut oil is to penetrate the cell wall so that the liquid will be sucked out and cause cell dredging and the death of microorganisms, in addition to the membrane shape of the structure of virgin coconut oil saturated fatty acids resembling bacterial or viral membrane structures and the size of small virgin coconut oil molecules so that they can more easily enter through the cell wall. Some types of bacteria are also reported to be turned off by monolaurin compounds such as Staphylococcus aureus, Helieobacter pylori (bacteria that cause heartburn) [9]. Studies on antimicrobials that include antiviral and antibacterial monolaurin by Kabara since 1965 reported that monolaurin is known to have antiviral bioactivity to RNA and DNA viruses in humans. The antibacterial of monolaurin only affects pathogenic bacteria. Its antibacterial properties can inhibit the growth of Streptococcus mutans and candida albicans as antifungal properties [10].

\subsubsection{Chemical Content of Gambir}

Gambir (Uncaria gambir Roxb.) is a plant that grows in the tropics and Asia [11]. This plant lives in free open areas in the forest, plantations, or edges of the forest at an altitude of 200 900 meters above sea level in humid areas, getting enough sunlight, even rainfall every year. Most of the gambir plants are in Sumatra and Kalimantan. Harvesting and pruning gambir is done at the age of 1.5 years as much as 2-3 times a year with an interval of 4-6 months [12].

Gambir extract is obtained from the sap of young leaves and twigs of plants that have been harvested. It is recommended to be directly processed within 24 hours so that the sap level is not reduced by boiling leaves and stalks for 1.5 hours and then squeezed to get the extract. The condensed extract is then placed in a container for 24 hours, then dried under sunlight for about 3 days to produce medicinal raw material of gambir in the form of

22 Zaadah et al. irregular cubes and somewhat cylindrical thickness ranges from 2-3 cm (Figure 2), light, easily broken, and diamonds. Light brown to reddish dark brown or blackish and light brown to yellowish on newly broken surfaces [11].

Gambir has the power content of astringent, antibacterial, and antifungal. The active substance of gambir extract is catechin in the form of pure catechin or catechol a polyphenol compound [13] and various other components. Catechin gambir can prevent the formation of extracellular glucans that serve to attach bacteria to the surface of the teeth, reduce the formation of plaque and kill pathogenic bacteria in the mouth, while catechol has the ability of antibacterial effects, inhibiting the activity of the enzyme glucosyltransferase. Inhibition of the activity of the enzyme glucosyltransferase causes a decrease in the synthesis of extracellular polymers associated with a decrease in the formation of dental plaque. Catechol prevents the attachment of bacteria to hydroxyapatite substances. Its interaction with bacterial surface proteins will reduce the hydrophobic power that plays a role in attaching bacteria to the surface of the teeth. Catechins that bind to the peptidoglycan components of bacterial cell walls cause bonds between bacteria to form biofilms to be severed [13].

\subsection{Research Objective}

This study aims to know the effect of the addition of gambir (Uncaria gambir Roxb) on the manufacture of virgin coconut oil (VCO) based herbal toothpaste on antibacterial properties, physical properties, and sensory values and to find the best treatment.

\section{MATERIALS AND METHODS}

\subsection{Material and Tools}

The materials used in this study were virgin coconut oil, gambir, Calcium carbonate, 70\% sorbitol solution, Glycerol, CMC, Saccharin, Propylparaben, Sodium lauryl ether sulfate, Menthol, Activated carbon, aquadest, $\mathrm{NaCl} 0.9 \%$, Mueller Hinton Agar (MHA), Mueller Hinton Broth (MHB), Media and Streptococcus mutans bacteria obtained at the Faculty of Medicine, Andalas University of West Sumatra. The tools used in the study consisted of mortar and pestle, Laminar Air Flow (LAF), mixer, autoclave, mortar, $\mathrm{pH}$ meter, oven, incubator, micropipette, bunsen, matchstick, spatula, test tube, pumpkin Erlenmeyer, stirrer rod, vortex, plastic vial, long gauge, funnel period, analytical balance, aluminum, cotton, time gauge, label, stationery, camera, tissue, foil, glass beaker, $50 \mathrm{ml}$ measuring glass, pipette, glass plate, spider and other glassware (pyrex).

\subsection{Design Experiment and Analysis}

The research design used is a Complete Randomized Design (CRD) with five treatments and three replications. The data is then analyzed using the F test and if the data is significant, it is continued by using Duncan News's Multiple Range Test (DNMRT) to find out the real difference of $5 \%$ between treatments. The treatment in this study is the percentage of addition of gambir to virgin coconut oil (VCO) based herbal toothpaste preparations as follows:

Treatment I: The addition of $0.9 \%$ of the weight of toothpaste Treatment II: The addition of $1.8 \%$ of the weight of toothpaste 
Treatment II: The addition of $1.8 \%$ of the weight of toothpaste Treatment IV: The addition of $1.8 \%$ of the weight of toothpaste Treatment V: The addition of $1.8 \%$ of the weight of toothpaste

\subsection{Implementation of Research}

\subsubsection{Preparation of Raw Materials}

Raw materials in this study used pure gambir extract with catechin content of $\geq 80 \%$ obtained and virgin coconut oil (pure coconut oil) pharmaceutical quality in accordance with the quality requirements of SNI 7381: 2008. Gambir obtained is mashed first with mortar and then sieved using 80 mesh so that the physical preparation of toothpaste is preferred and homogeneous according to the quality requirements of SNI 123524-1995.

\subsubsection{Toothpaste Production}

The manufacture of virgin coconut oil-based gambir herbal toothpaste was done based on the design of research modifications from Ref. [14] in Table 1 with the following steps: Mortar is first cleaned with $100{ }^{\circ} \mathrm{C}$ hot water, then water is removed from the mortar and dried. CMC is sprinkled over $100^{\circ} \mathrm{C}(20 \mathrm{ml}$ distilled water) eroded using mortar until homogeneous then let stand for \pm 15 minutes (mass 1 ). Calcium carbonate, $\mathrm{VCO}$, and gambir powder that has been salted are added then eroded until homogeneous, and then added activated carbon and a $70 \%$ sorbitol solution is eroded using mortar until homogeneous after that, inserted into mass one (mass 2). Saccharin and propyl parabens dissolved with half glycerol stirred until homogeneous then put into mass 2, gnawed using mortar until homogeneous. Sodium lauryl ether sulfate is dissolved until it dissolves into a mass of 2 little by little while continuing to be eroded using mortar until a homogeneous paste mass is formed. Add the rest of the Glycerol with Menthol to the mass of the paste eroded using mortar until homogeneous. Nonfermentation Cocoa Bean Processing

Cocoa beans that have been separated from the skin are directly dried in hybrid tempering at a temperature of $28-30^{\circ} \mathrm{C}$ for 5-7 days until the cocoa bean water content is obtained by $7 \%$.

Table 1. Toothpaste Manufacturing Treatment Composition. [modification of Ref.14]

\begin{tabular}{|c|c|c|c|c|c|c|c|}
\hline \multirow[t]{2}{*}{ No } & \multirow[t]{2}{*}{ Material } & \multirow[t]{2}{*}{ Function } & \multicolumn{5}{|c|}{ Treatments } \\
\hline & & & I & II & III & IV & $\mathbf{V}$ \\
\hline 1 & Gambir (g) & Active Material & 1 & 2 & 3 & 4 & 5 \\
\hline 2 & Virgin coconut oil $(g)$ & Basis & 10 & 10 & 10 & 10 & 10 \\
\hline 3 & Calsium Carbonate (g) & Filler & 44 & 44 & 44 & 44 & 44 \\
\hline 4 & Glyserol (g) & Humectant & 10 & 10 & 10 & 10 & 10 \\
\hline 5 & Sakarin $(g)$ & Sweetener & 0.2 & 0.2 & 0.2 & 0.2 & 0.2 \\
\hline 6 & $\begin{array}{l}\text { Sodium lauril ether } \\
\text { sulfate }(\mathrm{g})\end{array}$ & Surfactant & 1 & 1 & 1 & 1 & 1 \\
\hline 7 & Menthol (g) & Plavouring Agent & 1 & 1 & 1 & 1 & 1 \\
\hline 8 & Propil paraben (g) & Preservative & 0.1 & 0.1 & 0.1 & 0.1 & 0.1 \\
\hline 9 & $\mathrm{Na} \mathrm{CMC}(\mathrm{g})$ & $\begin{array}{l}\text { Gelling } \\
\text { agent }\end{array}$ & 2 & 2 & 2 & 2 & 2 \\
\hline 10 & Sorbitol (g) & Stabilizer & 10 & 10 & 10 & 10 & 10 \\
\hline 11 & Active Carbon (g) & Abrasive & 12 & 12 & 12 & 12 & 12 \\
\hline 12 & Aquadest (ml) & Solvent & 20 & 20 & 20 & 20 & 20 \\
\hline
\end{tabular}

Information:

$\mathrm{PI}=0.9 \% ; \mathrm{PII}=1.8 \% ; \mathrm{PIII}=2.6 \% ; \mathrm{PIV}=3.5 \% ; \mathrm{PV}=4.3 \%$ of toothpaste weight

\subsubsection{Observations of toothpaste treatment}

Observations include chemical analysis (pH test), physical analysis (homogeneity test and foaming test), sensory analysis (hedonic test), and microbiological analysis (antibacterial test). Methods of Analysis

\subsubsection{Homogeneity Test}

Homogeneity in toothpaste is done by placing a paste preparation between transparent glass plates, then swiping until it forms a thin layer. Homogeneity can be observed visually by looking at the absence of rough grains seen on glass objects. Observations based on SNI 12-3524-1995 are said to be homogeneous if there are no rough particles and air bubbles in sight.

\subsubsection{Foaming Test}

The foaming analysis is done by making a solution containing 1 gram, aquades $10 \mathrm{ml}$ (10\% concentration) of each toothpaste treatment into a $50 \mathrm{ml}$ measuring glass. Recorded initial volume preparations, then shuffled for 100 seconds as much as 200 times so that two shakes every second [15]. The foaming analysis is measured through the high addition of the foam formed [16].

\subsubsection{Antibacterial Analysis (Hafizah, 2019)}

Antibacterial activity tests are carried out using Muller Hinton Agar (MHA) media, namely Streptococcus mutans bacteria as much as $1 \mathrm{ml}$ from MHB media that have been suspended and then distributed evenly on MHA media. 
Furthermore, a $3 \mathrm{~mm}$ diameter well hole is made in Petri dish size of 100x20mm with medium height so that the poured MHA is $5 \mathrm{~mm}$. Then on each well is given toothpaste in accordance with the treatment of toothpaste tested. Petri dish containing toothpaste wells is incubated for 24 hours. Clear areas or bland zones formed in each well have then measured the diameter of the bland zone using the funnel term [16].

\subsubsection{Sensory Analysis}

The sensory analysis includes an analysis of the physical appearance of the final preparation of toothpaste that has been made by observing using the human senses as an instrument [17]. The method used is a hedonic test that serves to find out the level of consumer fondness for herbal toothpaste with the addition of virgin coconut oil-based gambir including aroma, color, taste, texture, and overall likes with a range scale of $1-5$, namely very like (5), like (4), ordinary (3), dislike (2), and very dislike (1). This test was conducted using panelists of as many as 20 people. Panelists are a group of people who assess a quality or give a subjective impression according to certain sense test steps [18].

\section{RESULTS AND DISCUSSION}

\section{1. $\quad$ pH Test}

PH measurements are done to determine the acidity level of toothpaste. The $\mathrm{pH}$ value determines the safety level of toothpaste so as not to irritate the oral mucosa [19]. (Nair, 2009). The acidic state in the mouth can increase the growth of nesting bacteria so that the measurement of $\mathrm{pH}$ values becomes one of the important indicators to be considered in the quality of toothpaste [20]. The results of $\mathrm{pH}$ testing in Table 9 obtained that the average $\mathrm{pH}$ value ranges from 8.19-8.74. This shows the parameters of the $\mathrm{pH}$ value of all virgin coconut oil-based herbal toothpaste treatments $(\mathrm{PI}=0.9 \%, \mathrm{PII}=1.8 \%, \mathrm{PIII}=2.6 \%$, PIV= $3.5 \%$, and $\mathrm{PV}=4.3 \%$ gambir) in the study conducted still in accordance with the quality requirements of toothpaste which is 4.5-11.0 so it is safe to use (SNI 12-3524-1995). The high pH value of each treatment is likely influenced by the composition of pasta fillers, namely Calcium carbonate $\left(\mathrm{CaCO}_{3}\right)$ as much as $40 \%$ [21].

Based on research data, the statistical test results of the oneway ANOVA method showed a significance of $0.00(\mathrm{p}<0.05)$ which means there is a real influence on the $\mathrm{pH}$ value of toothpaste formulas. Significant different data continued with Duncan News's Multiple Range Test (DNMRT).

Based on Figure 1, it can be concluded that treatment 3 is not significantly different from treatment 4 because it occupies the same subset column (subset), but there is a tendency to decrease the value of $\mathrm{pH}$ directly proportional to the addition of gambir concentrations in all treatments $(\mathrm{PI}=0.9 \%, \mathrm{PII}=1.8 \%$, $\mathrm{PIII}=2.6 \%$, PIV $=3.5 \%$ and $\mathrm{PV}=4.3 \%$ ) herbal toothpaste

based on virgin coconut oil. The gambir used in this study had a catechoic acid (catechoic acid) level of $\pm 80 \%$ with the chemical formula $\mathrm{C}_{15} \mathrm{H}_{14} \mathrm{O}_{6}$. According to the literature, the $\mathrm{pH}$ of gambir tends to be acidic. Catechin compounds are weak acids pKa $1=7.72$ and pKa 2 [22]., so the addition of acid to the base of toothpaste donates $\mathrm{H}^{+}$which affects $\mathrm{pH}$. Changes in $\mathrm{H}^{+}$ concentration will change oh $^{-}$concentration and vice versa [23].
Therefore, the more gambir is added, the lower the $\mathrm{pH}$ value of toothpaste treatment as shown in Figure 1.

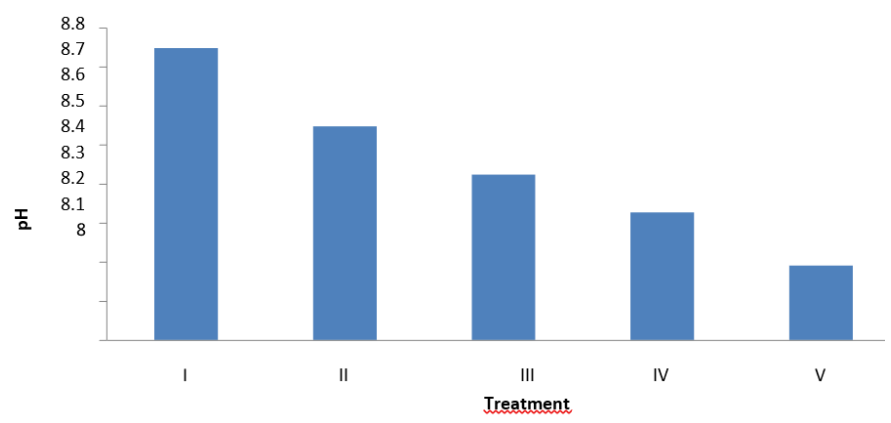

Figure 1. Graph of Average pH Measurements Facing Increased Concentration Gambir Toothpaste Treatment ( $\mathrm{PI}=0.9 \%$, $\mathrm{PII}=1.8 \%, \mathrm{PIII}=2.6 \%, \mathrm{PIV}=3.5 \%$ Dan $\mathrm{PV}=4.3 \%$ )

\subsection{Physical Analysis}

\subsubsection{Homogeneity Test}

Homogeneity testing is done to detect whether the ingredients used in the manufacture of toothpaste are homogeneously mixed to produce an even spread of function when applying the paste on the surface of the tooth [20]. Homogeneous indicators are characterized by color equations and no coarse particles are found in toothpaste (SNI 12-35241995).

Based on the results of the homogeneity test (Figure 2 ) on each treatment $(\mathrm{PI}=0.9 \%$; $\mathrm{PII}=1.8 \%$; $\mathrm{PIII}=2.6 \%$; $\mathrm{PIV}=3.5 \%$ and $\mathrm{PV}=4.3 \%$ of gambir) are declared homogeneous, i.e. the color of the paste is evenly distributed, soft, there are no coarse particles and clumps that can be seen or touched so that it is in accordance with the standard quality requirements of toothpaste.

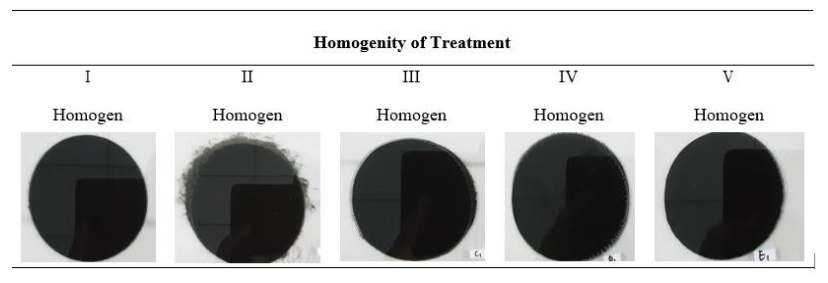

Figure 2. Homogenity Test Appearance (PI= $0.9 \%$, $\mathrm{PII}=1.8 \%$, $\mathrm{PIII}=2.6 \%, \mathrm{PIV}=3.5 \%$ and $\mathrm{PV}=4.3 \%$ of toothpaste weight)

\subsubsection{Foaming Test}

A foaming test is done to find out the ability to form toothpaste foam. The foam produced by toothpaste can add to the sensation of pleasure and consumer acceptance when applying the product. The allowed foam-forming material or surfactant is a maximum of $2 \%$. Surfactants added to the basis of this study treatment is Sodium lauryl ether sulfate (SLES) as much as $<2 \%$ so it is still safe to consume and does not cause irritation). Based on the results of research measuring the height of foam all herbal toothpaste treatments added gambir (Uncaria gambir Roxb) based virgin coconut oil (VCO) ranges from 8.1$12.1 \mathrm{~mm}$. According to the literature, the height criteria of toothpaste foam preparations in the market is a maximum of 15 $\mathrm{mm}$ [24]. This means that all treatments $(\mathrm{PI}=0.9 \%, \mathrm{PII}=1.8 \%$, $\mathrm{PIII}=2.6 \%, \mathrm{PIV}=3.5 \%$ and $\mathrm{F} 5=4.3 \%$ gambir) already meet the 
foam height criteria.. The statistical test data of the one way ANOVA method showed a significance of $0.003(\mathrm{p}<0.05)$ which means there is a noticeable influence on the addition of gambir concentrations on the formation of high foam toothpaste treatment. Significant different data continued Duncan's further tests. The change in foam height (Figure 3) due to the saponin content contained in gambir [25] is a glycoside contained in gambir plants and is a stable foam in aqueous solution, resulting from a combination of hydrophobic (fat-soluble) and hydrophilic (water-soluble) parts of the sugar chain.

The addition of gambir affects the concentration of saponins in high preparations of toothpaste so that the height of the foam produced and conversely the less the concentration of saponins the resulting is decreasing [26].

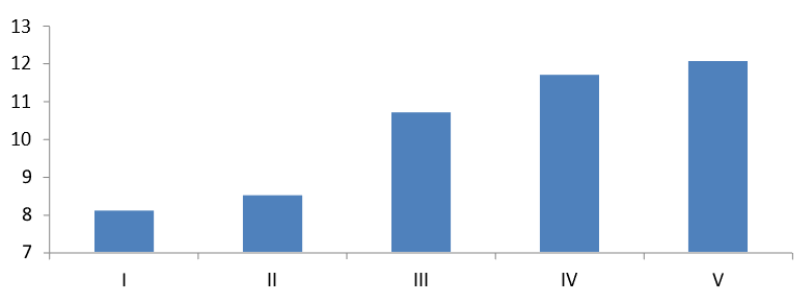

Figure 3. Graph of the average formation of foam height against the increase in the concentration of treatment gambir $(\mathrm{PI}=0.9 \%$, $\mathrm{PII}=1.8 \%, \mathrm{PIII}=2.6 \%, \mathrm{PIV}=3.5 \%$, and $\mathrm{PV}=4.3 \%$ )
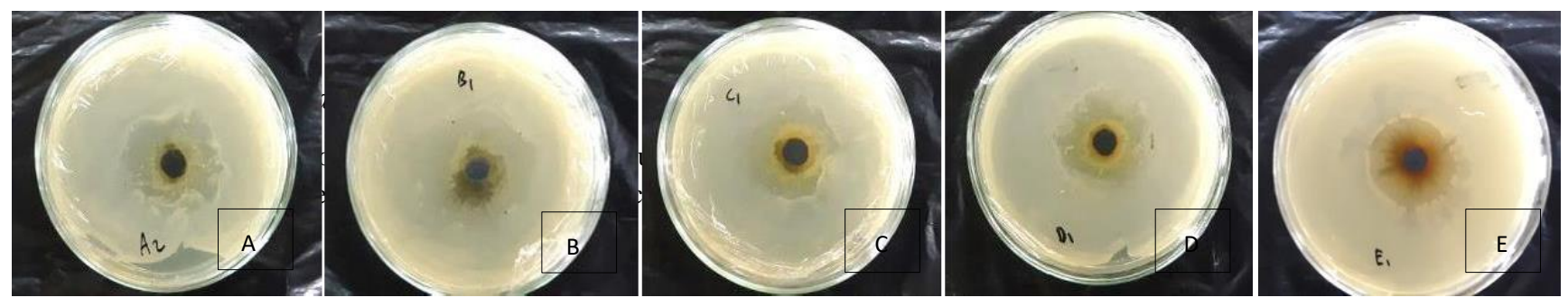

Figure 4. Diameter of Toothpaste Inhibition Zone $\mathrm{A}=\mathrm{PI}=0.9 \% ; \mathrm{B}=\mathrm{PII}=1.8 \%$; $=\mathrm{PIII}=2.6 \%$; $=\mathrm{PIV}=3.5 \%$; $=\mathrm{PV}=4.3 \%$ Gambir

ICatechins that have antibacterial activity power by a mechanism of work are based on denaturation and deposition of proteins in bacterial cells and enzyme inactivation. Catechins can kill the cariogenic bacteria Streptococcus mutans which produce two important enzymes, including glucosyltransferase (Gtf) converting sucrose into glucans involved in plaque formation and fructoseyltransferase (Ftf) converting fructose into fructans for use as energy reserves [29]. The antibacterial power of quercetin is to decrease protein synthesis in bacteria, affecting the expression of proteins in cells to cause cell lysis and bacterial death. Tannins can produce (deposition) proteins that provide antibacterial effects. Alkaloids can interfere with peptidoglycan components in bacterial cells so that the lining of the cell wall is not formed perfectly and causes cell death [30]. Antibacterial saponins can lower the surface tension of bacterial cell walls and impair membrane permeability thereby disrupting bacterial survival.

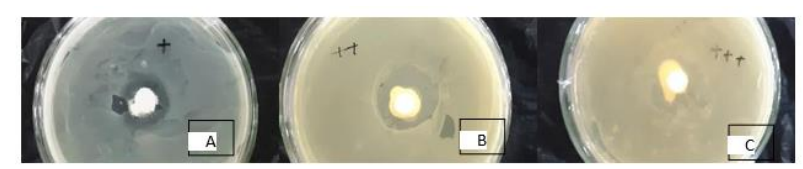

Figure 5. Inhibition Zone Diameter of Commercial Toothpaste;

\footnotetext{
A=Rep. I, B= Rep. II, C=Rep. III
}

antimicrobial agents of toothpaste by measuring the diameter of the clear zone (bland zone) formed around the well. The diameter value of the bland zone against antibacterial parameters $<10 \mathrm{~mm}$ is classified as non-existent, the diameter of the bland zone of $10-15 \mathrm{~mm}$ is classified as weak, the diameter of the bland zone of $16-20 \mathrm{~mm}$ is classified as moderate, and the diameter of the $>20 \mathrm{~mm}$ bland zone is classified as strong [27].

The results of the study of the bland zone values on all treatments $(\mathrm{PI}=0.9 \%, \mathrm{PII}=1.8 \%, \mathrm{PIII}=2.6 \%, \mathrm{PIV}=3.5 \%$, and $\mathrm{PV}=4.3 \%$ gambir) are classified as having strong antibacterial criteria i.e. $>20 \mathrm{~mm}$ bland zone. The diameter of the inhibition zone formed around the well of the test media indicates the absence of the growth of streptococcus mutans colonies (Figure 4).

The results of observations of herbal toothpaste the addition of virgin coconut oil-based gambir in this study are considered to have higher inhibition power compared to the commercial toothpaste treatment (Figure 5). According to the literature, gambir contains compounds of catechins, quercetin, tannins, alkaloids, and saponins that can act as antibacterial compounds inhibiting bacterial growth [28].

Based on the results of the one way ANOVA method statistical test obtained significance values of $0.671 \quad(p>0.05)$ showed that the addition of gambir concentrations of $0.9 \%$, $1.8 \%, 2.6 \%, 3.5 \%$, and $4.3 \%$ to toothpaste treatment was not significantly different, but there was a tendency to increase the diameter value of the inhibition zone. (Table 2 and Figure 6).

Table 2. Diameter of Inhibition Zone and Inhibition Criteria of Various Treatments

\begin{tabular}{|lll|}
\hline Treatment & $\begin{array}{l}\text { Diameter of Inhibition } \\
\text { Zone }(\mathrm{mm})\end{array}$ & Inhibition Criteria \\
\hline I & $31.67 \pm 1.37$ & Strong \\
II & $34.76 \pm 2.29$ & Strong \\
III & $34.55 \pm 2.40$ & Strong \\
IV & $31.90 \pm 2.96$ & Strong \\
V & $33.38 \pm 5.51$ & Strong \\
\hline
\end{tabular}




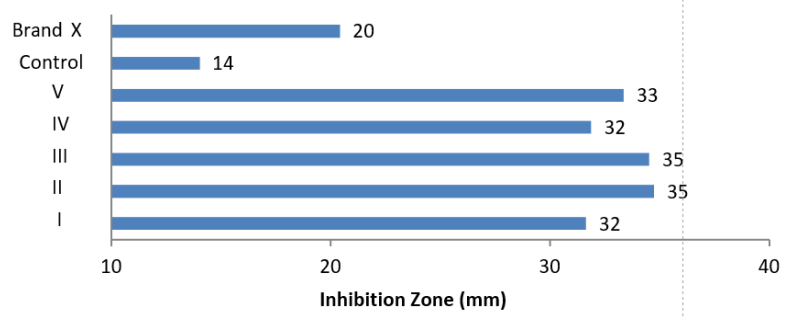

Figure 6. Graph of the average diameter of the toothpaste's bland zone against Streptococcus mutans

Measurement of base inhibition zone using virgin coconut oil ( $0 \%$ gambir) has a weak parameter bland power criteria of 14 $\mathrm{mm}$. The results of this measurement are in accordance with previous research, namely the testing of virgin coconut oil's bland power against the growth of Streptococcus mutans bacteria obtained an average diameter of the inhibition zone of $10.2 \mathrm{~mm}[32]$.

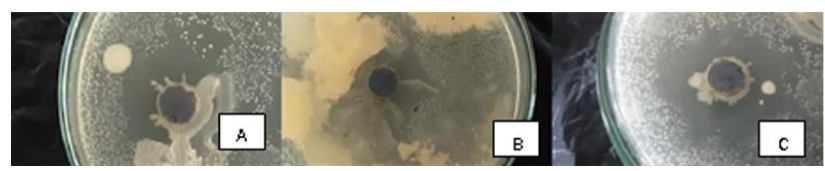

Figure 7 . Diameter of Inhibition Zone of Control (0\% Gambir); $\mathrm{A}=$ Rep. I, B= Rep.II, C=Rep. III

\subsection{Sensory Analysis}

Sensory tests are conducted to see consumer acceptance of toothpaste treatment including tests of color, aroma, taste, texture, and overall liking. The Hedonic test in this study used 20 untrained panelists of Andalas University, West Sumatra. Panelists assess 5 treatments with hedonic scales ranging from 1-5, namely; Very like (5), like (4), ordinary (3), dislike (2), and very dislike (1).

Color observation has an important role in assessing consumer acceptance of a product [33]. Color is the first sensor to be seen directly by Panelists. Based on the results of the study produced preparations of treatment of all toothpaste in dark black. The average parameter of color preferences of all treatments has a score ranging from 3.6-3.8 is considered to have a favorite-like value. The sample significance test data was 0.367 ( $p>0.05$ ) no different, meaning the data obtained was no meaningful difference. This is likely because the strong black dark color of activated carbon can mask the gambir color of the resulting toothpaste preparations. The most preferred treatment colors of panelists were treatment $3(2.6 \%)$, treatment $4(3.5 \%)$, treatment $5(\%)$, treatment $2(1.8 \%)$ then treatment $1(0.9 \%)$.

The aroma of toothpaste is observed using the sense of smell. The resulting research treatment has a fresh aroma typical of menthol and a little typical virgin coconut oil (VCO). The most preferred treatment of panelists was treatment $3(2.6 \%)$, treatment $4(3.5 \%)$, treatment $1(0.9 \%)$, treatment $2(1.8 \%)$ then treatment $5(4.3 \%)$. The sample significance test result data is 0.026 ( $p>0.005$ ) is no different, meaning the data obtained is no meaningful difference. This is likely due to the stronger distinctive aroma of menthol that can mask the distinctive aroma of each treatment.

Taste is a biological perception, like the sensation produced by a substance entering the mouth [34]. The test of fondness for taste in the teeth is observed with the taste buds for 1 minute in the oral cavity. The resulting treatment taste is slightly sweet with a fresh sensation (menthol). The resulting sweetness is obtained from the addition of saccharin. In addition, sorbitol and glycerol as stabilizers can be used as sweeteners because they produce a sweet taste commonly used in syrups or sweets [35]. Based on the data of the sample significance test results are 0.213 ( $p>0.05$ ) is not significantly different which means that the data obtained is no meaningful difference, but there is a tendency to decrease the number or the value of the scale of preference for the addition of gambir concentrations This is likely due to the fresh sensation of the typical taste of menthol, the sweetness of saccharin, sorbitol, and glycerol produced in each treatment strong enough to mask the typical taste of gambir.

The texture is a pressure sensation that can be observed by being seen and felt when bitten, chewed, swallowed, or groped using fingers [36]. The hedonic test of toothpaste texture in this study was observed with finger palpable senses, then panelists were assessed on a hedonic number scale. The texture produced in all treatments $(\mathrm{PI}=0.9 \%, \mathrm{PII}=1.8 \%, \mathrm{PIII}=2.6 \%, \mathrm{PIV}=3.5 \%$, and $\mathrm{PV}=4.3 \%$ gambir) results in soft toothpaste preparations with no separate clumps or particles in accordance with SNI quality requirements 12-3524-1994.

The sample significance test data is $0.898(\mathrm{p}>0.05)$ which means the data obtained is no different from real or no meaningful difference. This is likely due to the texture of the toothpaste base treatment being quite stable to the addition of gambir in a relatively small concentration. The textures most preferred by panelists were treatment $4(3.5 \%)$, treatment 2 $(1.8 \%)$, treatment $1(0.9 \%)$, treatment $3(2.6 \%)$, and treatment 5 $(4.3 \%)$.

Observation of the overall preferred fondness of virgin coconut oil (VCO) herbal toothpaste treatment to Table 16. The sample significance test data is $0.480(\mathrm{p}>0.05)$ which means the data obtained is no meaningful difference or no real difference. The overall preferred preferred test treatment of panelists was treatment $3(2.6 \%)$, treatment $2(1.8 \%)$, treatment $1(0.9 \%)$, treatment $4(3.5 \%)$, and treatment $5(4.3 \%)$. This is likely to increase the concentration of $2.6 \%$ is quite stable (optimal) overall, so it decreases in the value / hedonic rate at the addition of concentrations of $3.5 \%$ and $4.3 \%$. The physical appearance of toothpaste is listed in Figure 8.

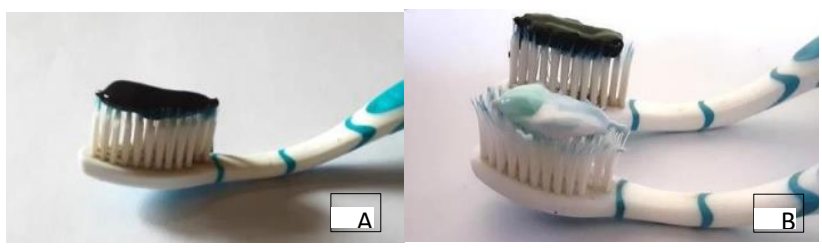

Figure 8. A=Treatment III (2.6\%); B=Comparison of Virgin Coconut Oil-Based Gambir Addition Toothpaste With Commercial Toothpaste.

\section{CONCLUSION}

Based on the research that has been done, it can be concluded as follows: (1) The addition of gambir concentrations has a real influence on the $\mathrm{pH}$ value and foam formation but does not affect homogeneity, hedonic values (color, aroma, taste, texture, 
and overall value) and the diameter of the bland zone against Streptococcus mutans bacteria; (2) The best toothpaste preparation is treatment 3 , which is the addition of $2.6 \%$ gambir from the toothpaste base preparation with a $\mathrm{pH}$ value of 8.42 , homogeneous, foam height of $10.70 \mathrm{~mm}$, color preference test: likes (3.85), the aroma of likes (4.25), taste: ordinary (3.30), texture: ordinary (3.45), overall: likes (3.80), strong indicator bland zone diameter $(34.55 \mathrm{~mm})$; (3) it is further recommended to carry out tests related to the shelf life of toothpaste to find out the effectiveness of the use of the product within a certain period.

\section{REFERENCE}

[1] Kidd E A, Bec S J 1992. Dasar-Dasar Karies Penyakit dan Penanggulangan (Alih bahasa: Narlan Sumawinata dan Saffida Faruk ) Jakarta: EGC

[2] Goldfaden, J., 2020. "Antibacterial Efficacy of Novel Eastern Medicine-Inspired Toothpastes Compared to Commercial Formulations," Student Scholar Symposium Abstracts and Posters.

[3] Anggina, D. N., dan Ramayanti, I. 2019. Perbandingan Efektivitas Berbagai Jenis Pasta Gigi Bahan Herbal dan Pasta Gigi Bahan Non Herbal Terhadap Pembentukan Plak. Syifa MEDIKA: Jurnal Kedokteran dan Kesehatan, 9(1), 1-9.

[4] Oroh, E. S., Posangi, J., dan Wowor, V. N. 2015. Perbandingan efektivitas pasta gigi herbal dengan pasta gigi non herbal terhadap penurunan indeks plak gigi. EGiGi, 3(2).

[5] Herdiansyah, R., Indriati, D., dan Komala., O. 2012 Formulasi Tablet Kunyah yang Mengandung Katekin Gambir (Uncaria gambir Roxb) sebagai Anti Bakteri (Streptococcus mutans) dalam Mulut. Program studi farmasi, FMIPA, Universitas Pakuan, 1-20

[6] Sukartin, K. dan Sitanggang M., 2005, Gempur Penyakit dengan VCO, 14-20, 36- 37, Jakarta : Agro Media Pustaka.

[7] Setiaji, B dan Surip P., 2006. Membuat VCO Berkualitas Tinggi. Jakarta : Penebar Swadaya. Jakarta.

[8] Dayrit, C.S. 2003. Coconut for Better Health. Quenzon City : Philippine Coconut Authority Auditorium.

[9] Rindengan, B dan Hengky, N. (2006). Virgin Coconut Oil , Pembuatan dan Pemanfaatan Minyak Kelapa Murni. Jakarta : Penebar Swadaya.

[10] Preuss, HG.,Fernando, D.,Bagchi M. Citrus aurantium as a thermogenic, weight-reduction replacement for ephedra: an overview. J Med 2002;33(1- 4):247-64.

[11] Anggraini, T., Akihiro T., Tomoyuki Y., dan Khairani, M. 2009. Pengaruh Sediaan Teh (Camellia Sinensis (L) O. Kuntze) Dan Madu Terhadap Bakteri Salmonella Typhi Schroeter Dan Staphylococcus Aureus Rosenbach. [Skripsi]. Universitas Andalas. Padang.

[12] Nazir, N., 2000, Gambir Budidaya, Pengolahan dan Prospek Diversifikasinya Padang. Padang: Yayasan Hutanku.

[13] [Risfaheri YL. Pengaruh ketuaan dan penanganan daun sebelum pengempaan terhadap rendemen dan mutu gambir. Bul Littro 1993; 8 (1): 47-51.

[14] Maesaroh, I., dan Silviani, S., 2019. Formulasi Sediaan Pasta Gigi Karbon Aktif Dengan Basis Virgin Coconut Oil (VCO), Jurnal Ilmiah Manuntung, 5(1), 8-17.

[15] Kumar, K., Jayachandra. E., Grindhar, B.R. 2009. Formulation and Evaluation Of Povidone Iodine Liquid Antidandruff Shampoo. Journal Of Pharmaceutical Science and Research. 1(3): 108-111.
[16] Afni, N., Said, N., 2015. Uji Aktivitas Antibakteri Pasta Gigi Ekstrak Biji Pinang (Areca Catechu L) Terhadap Streptococcus mutans dan Staphylococcus Aureu. Journal of Pharmacy Vol. 1 (1) :48 -58.

[17] Febria R. N. I. P., 2016. Formulasi Sediaan Gel Pasta Gigi Minyak Atsiri Kemangi dan Uji Aktivitas Antibakteri Terhadap Bakteri Streptococcus Mutans. Surakarta: Fakultas Farmasi Universitas Muhammadiyah.

[18] Setyaningsih, D., Apriyantono, A., dan Sari, M.P., 2010. Analisis Sensori untuk Industri Pangan dan Agro. Bogor: IPB Press.

[19] Nair, M., and Peate,I, 2009. Fundamentals of Applied Pathophysiology, John Wiley \& Sons. New Delhi..277 p

[20] Masduqi, F.A., Anggoro, A.B.,2017. Pemanfaatan Ekstrak Daun Belimbing Wuluh Sebagai Bahan Dasar Formula Pasta Gigi Dan Daya Antibakteri Streptococcus mutans. 12(1):1201-10.

[21] Rahman, D. A., 2009. Optimalisasi Formulas Sediian Gel Gigi Yang Mengandung Daun Jambu Biji (Psidium Guajava L) Dengan Na CMC Sebagai Gelling Agent. Skripsi : Program Studi Farmasi. Universitas Islam Negeri Syarif Hidayatulah.

[22] Lucida, H., Bakhtiar, A. Dan Putri, W.A. (2007). Formulasi sedian antiseptik mulut dari katekin gambir. Jurnal Sains Teknologi Farmasi 12(1): 1-7.

[23] Brown, Lemay, Bursten, Murphy. 2009. Chemistry The Central Science, 11th eds, Pearson Educational International, hal. 128-134, 666-716 .

[24] Marlina, D., Rosalini, N. 2017. Formulasi Pasta Gigi Gel Ekstrak Daun Sukun ( Artocarpus altilis ) Dengan Natrium CMC Sebagai Gelling Agent Dan Uji Kestabilan Fisiknya. Jurusan Farmasi Poltekkes Kemenkes Palembang. 12 (1).

[25] Isromarina, R., Rosa,E., dan Rusli, D., 2019. Aktivitas Anbakteri Ekstrak Daun Gambir (Uncaria Gambir (Hunter) Roxb) Terhadap Bakteri Vibrio Cholerae Atcc 14033. Jurnal Ilmiah Bakti Farmasi, 2019, IV(1), hal. 21-26.

[26] Cheeke, P. R. (2011). Biological Effects Of Feed And Forage Saponins And Their Impacts On Animal Production. In Saponins Used In Food And Agriculture., 377-385.

[27] Greenwood. 1995. Antibiotic susceptibility (sensitive) Test, Antimicrobial and chemotherapy. USA: Mc Graw Hill Company.

[28] Risdale CE. 2002. A review of Uncaria rubiaceae. J. of Blumea. 24:43-100.

[29] Gani, B.A., Tanzil, A., Mangundjaja, S., 2006. Aspek molekuler sifat virulensi Streptococcus mutans. Indonesian Journal of Dentistry. 13(2):107-14.

[30] Karou, D., Dicko, M. H., Simpore, J., \& Traore, A. S., 2005, Antioxidant and Antibacterial Activities of Polyphenol From Ethnomedicinal Plant of Burkina Faso, African Journal of Biotechnology, 4 (8), 823-828.

[31] Madduluri, Suresh. Rao, K.Babu. Sitaram, B. (2013). In Vitro Evaluation of Antibacterial Activity Of Five Indigenous Plants Extract Against Five Bacterial Pathogens Of Human. International Journal Of Pharmacy And Pharmaceutical Sciences, 5(4), 679-684.

[32] Hassan, E.H., 2019. Uji Daya Hambat Virgin Coconut Oil Plus terhadap Pertumbuhan Bakteri S.mutans. Jurnal e-Gigi (Eg), 7 (1): 31-32.

[33] Fitriani, T. K., 2011. Kajian Penambahan Ekstrak dan Tepung Wortel Terhadap Karakteristik Fisik, Kimia,dan Sensoris Es Krim. Naskah Skripsi-S1. Fakultas Pertanian Universitas Sebelas Maret. Surakarta. 
[34] Claret, M. T.,2018. Uji Aktivitas Antioksidan dan Kesukaan Panelis Terhadap Es Krim Sari Serai (Cymbopogon Citratus). Program Studi pendidikan Biologi. Universitas Sanata Dharma. Yogyakarta.

[35] Armstrong, N. A., 2009, Sucrose in Rowe C. R., Sheskey, P. J., and Owen, S. C., (Eds)., Handbook of Pharmaceutical Exipients, 6th Edition, Pharmaceutical Press, London.

[36] Aliyah,R., 2010. Pengaruh Jenis Bahan Pengental Dalam Pembuatan Es Krim Sari Wortel Terhadap Kadar Betakaroten dan Sifat Inderawi. Skripsi Universitas Negeri Semarang 